\title{
Prediction of ADME-Tox properties and toxicological endpoints of triazole fungicides used for cereals protection
}

\author{
Ionuț Mădălin Gridan ${ }^{1}$, Alecu Aurel Ciorsac ${ }^{2}$ and Adriana Isvoran ${ }^{1, *}$ \\ ${ }^{1}$ Department of Biology-Chemistry and Advanced Environmental Research Laboratories, West University of Timișoara, \\ Timișoara, Romania \\ ${ }^{2}$ Department of Physical Education and Sport, University Politehnica Timișoara, Timișoara, Romania;
}

*Corresponding Author: E-mail: adriana.isvoran@e-uvt.ro; Tel.: +40-256-592-634; Fax: +40-256-592-620

Received: February 25, 2019; Revised: May 02, 2019; Published: May 21, 2019

\begin{abstract}
Within this study we have considered 9 triazole fungicides that are approved to be used in European Union for protecting cereals: cyproconazole, epoxiconazole, flutriafol, metconazole, paclobutrazole, tebuconazole, tetraconazole, triadimenol and triticonazole. We have summarized the few available data that support their effects on humans and used various computational tools to obtain a widely view concerning their possible harmful effects on humans. The results of our predictive study reflect that all triazole fungicides considered in this study reveal good oral bioavailability, are envisaged as being able to penetrate the blood brain barrier and to interact with P-glycoprotein and with hepatic cytochromes. The predictions concerning the toxicological endpoints for the investigated triazole fungicides reveal that they. reflect potential of skin sensitization, of blockage of the $h E R G K+$ channels and of endocrine disruption, that they have not mutagenic potential and their carcinogenic potential is not clear. Epoxiconazole and triadimenol are predicted to have the highest potentials of producing numerous harmful effects on humans and their use should be avoided or limited.
\end{abstract}

\section{Keywords}

oral bioavailability; endocrine disruption; carcinogenicity; mutagenicity; cardiotoxicity

\section{Introduction}

Pesticides are a broad class of chemical compounds that are deliberately used on a planetary basis since several decades in the control of pests and vectors of diseases. In spite of the benefits of their use, their continued application and their release into various ecosystems has become a matter of concern for both humans and environment [1]. The general population is exposed to low dose of pesticides repeated over time through the food, domestic use and environment [2]. A significant risk of exposure to pesticides is registered by the people engaged in agriculture [3] and for those people living close to a workplace that uses pesticides [4]. Literature data suggest the relationship between pesticide exposure and several human pathologies: cancer, endocrine disruption, diabetes, neurologic and reproductive disorders [5,6].

There are more than 1000 active ingredients on various types of pesticides used worldwide [7]. Furthermore, the formulation of new pesticides is growing due to the appearance of resistant pests, growing global population and regulation of pesticides. The use of some pesticides such as carbamates and 
organophosphates decreased since 2007, but the use of triazoles have significantly increased after 2007 [8]. Triazole agents are heterocyclic compounds having a five-membered ring of two carbon and three nitrogen atoms that are widely used as antifungal agents in both medicine and in agriculture [9]. They represent around a third of the fungicides used for the protection of crop yields [10] and an important fungicide category used in the prevention of cereals diseases [11].

The residues of triazole agricultural fungicides have been frequently detected in numerous human and environmental media and there are reported toxicity data that have led them as compounds with health concern [12]. Within this study we focus our attention on the triazole fungicides that are approved to be used in European Union for protecting cereals [13]: cyproconazole, epoxiconazole, flutriafol, metconazole, paclobutrazole, tebuconazole, tetraconazole, triadimenol and triticonazole. The structural formulas of these compounds are illustrated in the Figure 1. The routes of exposure for these chemicals usually are inhalation and dermal contact, but the oral route can be also considered as they could be found in food $[4,6]$.

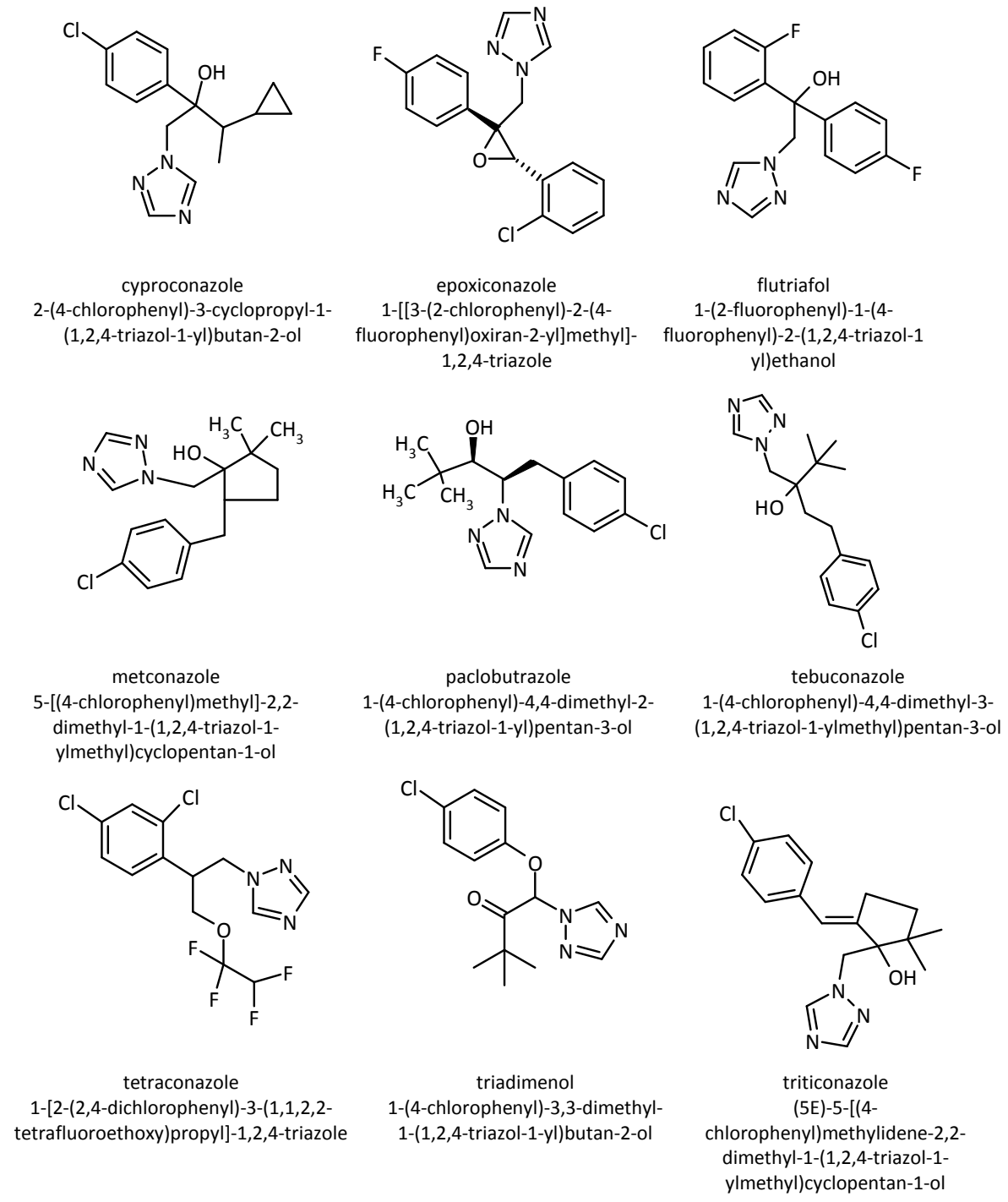

Figure 1. Structural formulas of triazole fungicides considered in the present study, their common and IUPAC names

Regulatory agencies establish standard approaches to risk assessment of chemicals. Taking into account the ethics principles of conducting large-scale, long-term and highly invasive toxicity tests in humans, the risk assessment tests are usually based on toxicity studies conducted in animals. There also are important 
data resulting from accidental human exposures to chemicals (occupational exposure, industrial accidents, unintentional environmental releases) that are considered when setting regulatory standards to protect public health. Both scientific community and large society is divided in supporters and critics, and there are arguments for and against the intentional human dosing studies [14]. Transfer of data obtained through animal tests to humans usually depend on the ability of measuring the same endpoints in animals and data obtained from studies on humans subjects are considered more relevant for assessing toxicity than data obtained from tests on animals.

Considering the costs and the ethical concerns on using both humans and animals for testing purposes, the role of computational approaches in hazard assessment become recognized. The amount and diversity of data obtained through experimental toxicity studies allowed the building of truthful computational models for toxicology assessment. It also conducted to the development of various computational tools that can be used for hazard assessment. They are recognized by the Organization of Economic and Cooperation Development (OECD) [15] and European Food Safety Association [16] and are constantly used nowadays in assessing the toxicological effects of various chemicals on humans [17-21]. Besides the large applicability of these tools for human hazard assessment, there are some limitations mostly related to the predictability of training models and to the fact that they do not take into account the dose. We use some of these computational tools in our study and taking into account that they are meant to predict the effects on humans, for validation purposes we have only collected data obtained from human exposure on triazole fungicides.

Specific literature data contains some information concerning the effects of these triazole fungicides on the human health. We have collected data from the specific literature and toxicity databases: TOXNET/Hazardous Substances Data Bank (HSDB) [https://toxnet.nlm.nih.gov], Occupational Safety and Health Administration (OSHA) [https://www.osha.gov], National Institute of Occupational Safety and Health (NIOSH) / Pocket Guide to Chemical Hazards [http://www.aresok.org/npg/nioshdbs/npg/default.html], PAN Pesticide Database (http://www.pesticideinfo.org), PubChem (https://pubchem.ncbi.nlm.nih.gov), and Pesticides Properties DataBase (PPDB, https://sitem.herts.ac.uk/aeru/ppdb/en) available on January-February 2019. Available information is presented in Table 1.

$\mathrm{NIOSH}$ and OSHA databases do not contain data concerning the toxic effects of investigated triazole fungicides. Also, there is no information concerning their cardiotoxicity. Besides the information presented in table 1, there are other few known effects of triazole fungicides: flutriafol is known to produce anaemia (PPDB), paclobutrazole is considered harmful if inhaled or swallowed (PPDB), tebuconazole is considered harmful if swallowed (PubChem) and triadimenol may cause nausea, headache, sneezing and vomiting (TOXNET). Data in Table 1 illustrate that toxicological data from human exposure to pesticides are limited and sometimes controversial.

The aim of this study is to use various computational algorithms to predict the ADME-Tox profiles and toxicological endpoints of the triazole fungicides used for cereals protection in European Union.

\section{Method}

Specific literature is abundant in computational tools available for predicting ADMET profiles and biological effects of chemicals (for more information concerning available tools, please visit http://www.vls3d.com/index.php/links/chemoinformatics/admet/admet-and-physchem-predictions-andrelated-tools). We have selected for our study a few computational tools that are free accessible online, are continuously updated, are robust and their accuracy of predictions is higher than $70 \%$. 
Table 1. Known human health effects of triazole fungicides used for cereals protection

\begin{tabular}{|c|c|c|c|c|c|c|c|}
\hline $\begin{array}{l}\text { Triazole } \\
\text { fungicide }\end{array}$ & $\begin{array}{l}\text { Skin/eye } \\
\text { irritations }\end{array}$ & $\begin{array}{l}\text { Respiratory } \\
\text { tract } \\
\text { irritant }\end{array}$ & $\begin{array}{l}\text { Carcinogenicity } \\
\text { /Mutagenicity }\end{array}$ & $\begin{array}{l}\text { Endocrine disruption } \\
\text { potential }\end{array}$ & $\begin{array}{l}\text { Reproductive } \\
\text { toxicity }\end{array}$ & $\begin{array}{l}\text { Hepato- } \\
\text { toxicity }\end{array}$ & $\begin{array}{l}\text { Neuro- } \\
\text { toxicity }\end{array}$ \\
\hline cyproconazole & $\begin{array}{l}\text { Mild eye } \\
\text { irritant } \\
\text { (TOXNET), } \\
\text { skin and } \\
\text { eye irritant } \\
\text { (PPDB) }\end{array}$ & Yes (PPDB) & $\begin{array}{l}\text { Probable } \\
\text { carcinogen } \\
\text { (TOXNET, PAN) } \\
\text { /No data found. }\end{array}$ & $\begin{array}{l}\text { Inhibition of } \\
\text { aromatase activity, } \\
\text { decrease of estrogens } \\
\text { production (PPDB) }\end{array}$ & $\begin{array}{l}\text { No data } \\
\text { found. }\end{array}$ & $\begin{array}{l}\text { Possible } \\
\text { liver } \\
\text { toxicant } \\
\text { (PPDB) }\end{array}$ & $\begin{array}{l}\text { No } \\
\text { (PPDB) }\end{array}$ \\
\hline epoxiconazole & No (PPDB) & No (PPDB) & $\begin{array}{l}\text { probable } \\
\text { carcinogen } \\
\text { (PPDB, } \\
\text { PubChem, } \\
\text { PAN)/ No data } \\
\text { found. }\end{array}$ & $\begin{array}{l}\text { inhibition of } \\
\text { aromatase activity, } \\
\text { decrease of estrogen } \\
\text { production (PPDB), } \\
\text { suspect to produce } \\
\text { endocrine disruption } \\
\text { (PAN) }\end{array}$ & $\begin{array}{l}\text { No data } \\
\text { found. }\end{array}$ & $\begin{array}{l}\text { Liver } \\
\text { toxicant } \\
\text { (PPDB) }\end{array}$ & $\begin{array}{l}\text { No } \\
\text { (PPDB) }\end{array}$ \\
\hline flutriafol & NO (PPDB) & Yes (PPDB) & $\begin{array}{l}\text { No (PPDB, } \\
\text { PAN)/ No data } \\
\text { found. }\end{array}$ & $\begin{array}{l}\text { Weak estrogen } \\
\text { inhibition (PPDB), } \\
\text { suspect to produce } \\
\text { endocrine disruption } \\
\text { (PAN) }\end{array}$ & $\begin{array}{l}\text { No data } \\
\text { found. }\end{array}$ & $\begin{array}{l}\text { Possible } \\
\text { liver } \\
\text { toxicant } \\
\text { (PPDB) }\end{array}$ & $\begin{array}{l}\text { No } \\
\text { (PPDB) }\end{array}$ \\
\hline metconazole & $\begin{array}{l}\text { NO (PPDB) } \\
\text { Yes } \\
\text { (PubChem) }\end{array}$ & Yes (PPDB) & $\begin{array}{l}\text { No (PPDB, } \\
\text { PAN)/ No data } \\
\text { found. }\end{array}$ & No data found. & $\begin{array}{l}\text { Suspect of } \\
\text { damaging } \\
\text { fertility or } \\
\text { the unborn } \\
\text { child. } \\
\text { (PubChem) }\end{array}$ & $\begin{array}{l}\text { Possible } \\
\text { liver } \\
\text { toxicant } \\
\text { (PPDB) }\end{array}$ & $\begin{array}{l}\text { No } \\
\text { (PPDB) }\end{array}$ \\
\hline paclobutrazole & $\begin{array}{l}\text { Yes (PPDB, } \\
\text { PubChem) }\end{array}$ & $\begin{array}{l}\text { No data } \\
\text { found. }\end{array}$ & $\begin{array}{l}\text { NO (PPDB)/ } \\
\text { No data found. }\end{array}$ & No data found. & $\begin{array}{l}\text { Suspect of } \\
\text { damaging } \\
\text { fertility or } \\
\text { the unborn } \\
\text { child. } \\
\text { (PubChem) }\end{array}$ & $\begin{array}{l}\text { No data } \\
\text { found. }\end{array}$ & $\begin{array}{l}\text { No } \\
\text { (PPDB) }\end{array}$ \\
\hline tebuconazole & $\begin{array}{l}\text { Eye irritant } \\
\text { (PPDB) }\end{array}$ & No (PPDB) & $\begin{array}{l}\text { probable } \\
\text { carcinogen } \\
\text { (TOXNET, PAN)/ } \\
\text { NO (PPDB) }\end{array}$ & $\begin{array}{l}\text { NO (PPDB), suspect } \\
\text { to produce endocrine } \\
\text { disruption (PAN) }\end{array}$ & $\begin{array}{l}\text { Yes (PPDB, } \\
\text { PubChem) }\end{array}$ & $\begin{array}{l}\text { No data } \\
\text { found. }\end{array}$ & $\begin{array}{l}\text { No } \\
\text { (PPDB) }\end{array}$ \\
\hline tetraconazole & $\begin{array}{l}\text { Eye irritant } \\
\text { (TOXNET), } \\
\text { no effects } \\
\text { (PPDB) }\end{array}$ & $\begin{array}{l}\text { No } \\
\text { (ToxNET, } \\
\text { PPDB) }\end{array}$ & $\begin{array}{l}\text { probable } \\
\text { carcinogen } \\
\text { (TOXNET, PPDB, } \\
\text { PAN)/ No } \\
\text { (PPDB) }\end{array}$ & No (PPDB) & $\begin{array}{l}\text { No data } \\
\text { found. }\end{array}$ & $\begin{array}{l}\text { Liver } \\
\text { toxicant } \\
\text { (PPDB) }\end{array}$ & $\begin{array}{l}\text { No } \\
\text { (PPDB) }\end{array}$ \\
\hline triadimenol & $\begin{array}{l}\text { Yes } \\
\text { (TOXNET, } \\
\text { PPDB) }\end{array}$ & $\begin{array}{l}\text { YES } \\
\text { (TOXNET, } \\
\text { PPDB) }\end{array}$ & $\begin{array}{l}\text { probable } \\
\text { carcinogen } \\
\text { (PPDB, PAN)/ } \\
\text { No data found. }\end{array}$ & $\begin{array}{l}\text { Yes (TOXNET), } \\
\text { estrogenic effect } \\
\text { (PPDB), suspect to } \\
\text { produce endocrine } \\
\text { disruption (PAN) }\end{array}$ & $\begin{array}{l}\text { Yes (PPDB, } \\
\text { PubChem) }\end{array}$ & $\begin{array}{l}\text { Liver } \\
\text { toxicant } \\
\text { (PPDB) }\end{array}$ & $\begin{array}{l}\text { No data } \\
\text { found. }\end{array}$ \\
\hline triticonazole & No (PPDB) & No (PPDB) & $\begin{array}{l}\text { probable } \\
\text { carcinogen } \\
\text { (TOXNET), } \\
\text { noncarcinogen } \\
\text { (PPDB)/ No data } \\
\text { found. }\end{array}$ & No data found. & $\begin{array}{l}\text { No data } \\
\text { found. }\end{array}$ & $\begin{array}{l}\text { No data } \\
\text { found. }\end{array}$ & $\begin{array}{l}\text { No data } \\
\text { found. }\end{array}$ \\
\hline
\end{tabular}

FAFDrugs (now arrived to version 4) is an online tool that can be used for the computational prediction of the ADMET profile based on filtering rules that take into account some physicochemical descriptors (molecular weight, polar surface area, $\log P$, number of hydrogen bonds donors and acceptors, or number of rigid or rotatable bonds, etc.) [22]. It requires as input the structural data file (SDF) of the investigated compound and outputs a summary result page and a detailed result page for every analysed compound. The summary result page contains a brief statistical summary of the filtering process with graphical representations of the distributions of numerous properties, illustrating all computed values. The detailed 
result page contains a list of all encountered problems (if it is the case), radar plots illustrating how the compound's properties fit into the defined physicochemical filter, a principal component analysis mapping the analysed compound into the oral chemical space of drugs, the oral bioavailability assessment considering Lipinski, Veber, Egan and Bayer rules and a drug safety profiling based on the GSK 4/400 rule, Pfizer 3/75 rule, estimation of phospholipidosis inducing and the Lilly MedChem rules with a minimum of $70 \%$ of accuracy. When computing the Lilly MedChem rules [23], the regular demerit level has been applied.

SwissADME [24] computational facility has been used to predict pharmacokinetics of investigated triazole fungicides. For every investigated compound, SwissADME outputs predictions concerning the: passive human gastrointestinal absorption (GI), blood-brain barrier (BBB) permeation, skin penetration coefficient, substrate or non-substrate of the permeability glycoprotein (P-gp), interaction of molecules with five major isoforms of the human cytochromes P450 (CYP1A2, CYP2C19, CYP2C9, CYP2D6, CYP3A4) known to be involved in the metabolism of numerous endogenous and exogenous compounds [24]. The statistical performance of the classification models used by SwissADME for predicting pharmacokinetics profile is between $72 \%$ and $94 \%$.

As dermal exposure to triazole fungicides is not negligible, we have used PredSkin [25] computational tool to assess the skin sensitization potential of investigated compounds. This application is based on binary QSAR models of skin sensitization potential using human and murine local lymph node assay data (LLNA) (performance ranging between 70 and $84 \%$ ) and a multiclass skin sensitization potential model based on LLNA data (performance being about 73 \%). The application also outputs, for every compound, a probability map illustrating the predicted contribution to skin sensitization potential of chemical fragments [25].

Pred-hERG is a web tool based on Quantitative Structure-Activity Relationship (QSAR) models built on the curated dataset of 5,984 compounds and used to predict the hERG K+ channel blockage. Three outcomes are available when using Pred-hERG: predictions using a binary model (accuracy $80 \%$ ), predictions using a multi-class model (accuracy $70 \%$ ) and a probability map of atomic contribution to hERG $\mathrm{K}(+)$ channels blockage [26].

CarcinoPred-EL (Carcinogenicity Prediction using Ensemble Learning methods) is a web server allowing the classification of chemical compounds as carcinogens or non-carcinogens starting from their twodimensional structures [27]. This web server incorporates three ensemble learning models (Ensemble XGBoost, Ensemble SVM and Ensemble RF) for predicting the carcinogenicity of chemicals. Ensemble XGBoost model gives the highest accuracy of predictions (70.1\%) [27]. Mutagenicity of considered triazole fungicides has been predicted using Ames test implemented under the open source Toxtree software [28]. This is an open source application that estimates mutagenicity by applying a decision tree approach based on Benigni and Bosa rules [29] with an accuracy of about $79 \%$.

Endocrine disruption potential of investigated fungicides has been evaluated using ENDOCRINE DISRUPTOME computational tool [30]. It uses the molecular docking approach based on AutoDock Vina algorithm to predict the interactions between the investigated chemicals and human nuclear receptors: androgen receptor, estrogen receptors $\alpha$ and $\beta$, glucocorticoid receptor, liver $X$ receptors $\alpha$ and $\beta$, peroxisome proliferator activated receptors $\alpha, \beta / \delta$ and $\gamma$, retinoid $X$ receptor $\alpha$ and thyroid receptors $\alpha$ and $\beta$ [24]. In the results section, three thresholds, calculated from the docking score and the validation experiments and expressed as sensitivity (SE) parameter, were set for every structure allowing a division 
into 4 probability binding classes: compounds with high probability of binding $(\mathrm{SE}<0.25)$, compounds with intermediate probability of binding $(0.25<\mathrm{SE}<0.50)$, compounds with moderate probability of binding, $(0.50<\mathrm{SE}<0.75)$ and Compounds with low probability of binding (SE $>0.75)$ [30].

\section{Results and Discussion}

ADMET profiles of investigated fungicides have been obtained using FAFDrugs4 and respectively SwissADME computational facilities and are illustrated in tables 2 and 3. Data presented in Tables 2 and 3 illustrate that all investigated triazole fungicides have good oral bioavailability, can be easily absorbed in the gastrointestinal tract and, consequently, are able to reach the systemic blood circulation and to produce various biologic effects.

Every investigated compound is predicted to have at least a mean toxicity when applying Pfizer rule, the toxicity being related to their content in halogen atoms and, in the case of epoxiconazole, the epoxide group also reflect toxicity. Epoxiconazole and triadimenol also do not pass Lilly MedChem rules meaning that these two pesticides may illustrate activities that damage proteins [23]. None of investigated compounds is predicted to induce phospholipidoses (data not shown).

Table 2. Prediction of the ADMET profiles obtained using the FAFDrugs4 computational tool for the triazole fungicides considered in this study: green boxes correspond to rules that are respected, orange boxes correspond to rules that are partially violated and red grey boxes correspond to rules that are not respected.

\begin{tabular}{|c|c|c|c|c|c|c|c|}
\hline \multirow[b]{2}{*}{$\begin{array}{l}\text { Triazole } \\
\text { fungicide }\end{array}$} & \multicolumn{4}{|c|}{ Oral Bioavailability } & \multicolumn{3}{|c|}{ Drug Safety Profiling } \\
\hline & $\begin{array}{l}\text { Lipinski’s } \\
\text { rule }\end{array}$ & $\begin{array}{l}\text { Veber's } \\
\text { rule }\end{array}$ & $\begin{array}{l}\text { Eagan's } \\
\text { rule }\end{array}$ & $\begin{array}{c}\text { Bayer } \\
\text { rule }\end{array}$ & $\begin{array}{c}\text { GSK } \\
\text { 4/400 rule }\end{array}$ & $\begin{array}{c}\text { Pfeizer } 3 / 75 \\
\text { rule }\end{array}$ & $\begin{array}{l}\text { Lilly MedChem } \\
\text { rules }\end{array}$ \\
\hline \multicolumn{8}{|l|}{ cyproconazole } \\
\hline \multicolumn{8}{|l|}{ epoxiconazole } \\
\hline \multicolumn{8}{|l|}{ flutriafol } \\
\hline \multicolumn{8}{|l|}{ metconazole } \\
\hline \multicolumn{8}{|c|}{ paclobutrazole } \\
\hline \multicolumn{8}{|l|}{ tebuconazole } \\
\hline \multicolumn{8}{|l|}{ triticonazole } \\
\hline \multicolumn{8}{|l|}{ triadimenol } \\
\hline tetraconazole & & & & & & & \\
\hline
\end{tabular}

Table 3. Prediction of the pharmacokinetics profiles of the triazole fungicides using SwissADME computational tool: GIgastrointestinal absorption, BBB- blood brain barrier permeant, P-gp - P-glycoprotein, CYP - human cytochrome, log $K_{\mathrm{p}}$ - skin penetration coefficient in logarithmic scale.

\begin{tabular}{|c|c|c|c|c|c|c|c|c|c|}
\hline $\begin{array}{c}\text { Active } \\
\text { substance }\end{array}$ & $\begin{array}{c}\mathrm{GI} \\
\text { absorption }\end{array}$ & $\begin{array}{c}\text { BBB } \\
\text { permeant }\end{array}$ & $\begin{array}{c}\text { P-gp } \\
\text { substrate }\end{array}$ & $\begin{array}{l}\text { CYP1A2 } \\
\text { Inhibitor }\end{array}$ & $\begin{array}{l}\text { CYP2C19 } \\
\text { Inhibitor }\end{array}$ & $\begin{array}{l}\text { CYP2C9 } \\
\text { Inhibitor }\end{array}$ & $\begin{array}{l}\text { CYP2D6 } \\
\text { Inhibitor }\end{array}$ & $\begin{array}{l}\text { CYP3A4 } \\
\text { Inhibitor }\end{array}$ & $\log K_{\mathrm{p}}$ \\
\hline cyproconazole & High & Yes & No & No & Yes & No & No & No & -6.02 \\
\hline epoxiconazole & High & Yes & Yes & No & Yes & Yes & Yes & No & -5.87 \\
\hline flutriafol & High & Yes & No & No & Yes & No & Yes & No & -6.50 \\
\hline metconazole & High & Yes & No & No & Yes & No & Yes & No & -5.52 \\
\hline paclobutrazole & High & Yes & No & No & Yes & No & No & No & -5.82 \\
\hline tebuconazole & High & Yes & No & Yes & Yes & No & Yes & No & -5.55 \\
\hline triticonazole & High & Yes & Yes & No & Yes & Yes & No & No & -5.87 \\
\hline triadimenol & High & Yes & No & No & Yes & No & No & No & -5.92 \\
\hline tetraconazole & High & Yes & No & Yes & Yes & Yes & No & No & -6.04 \\
\hline
\end{tabular}

All investigated fungicides are predicted as being able to penetrate the blood brain barrier and it illustrates their potential to affect the central nervous system, and/or the transport of nutrients, drugs and waste products into and out of the brain. Available information illustrates that most of investigated triazoled fungicides do not produce human neurotoxicity (see Table 1), but there are published data exemplifying neurotoxic effects of these compounds on rats [31-32]. Epoxyconazole and triticonazole are 
predicted as P-gp substrates and it illustrates their possible active efflux both from the gastrointestinal tract to the lumen and from the brain, being known that one of the roles of P-gp is to protect the central nervous system from xenobiotics. The predictions are in good agreement with literature data revealing that the triazoles are substrates and/or inhibitors of transport proteins in the ATP-binding cassette transporter protein family [33]. Furthers studies are necessary for assessing the risk of neurotoxicity of trizole fungicides on humans.

All investigated fungicides are predicted to be able to inhibit CYP2C19 and some of them are also able to inhibit CYP1A2, CYP2C9 and/or CYP2D6. These predictions are in good agreement with published data concerning the interactions of triazole antifungal human drugs with hepatic CYPs. Literature data reveal that triazole antifungal agents as human drugs are substrates and inhibitors of various CYPs [34], including CYP3A4, CYP2C19 and CYP2C9 that are involved in catalysing the triazole biotransformation [35]. It is possible that investigated triazole fungicides to be metabolized by CYPs. In this case, the polymorphisms within these enzymes may conduct in their accumulation into the human organism. The inhibition of human CYPs involved in the metabolism of many endogenous compounds and of xenobiotics by the investigated triazole fungicides may conduct to pharmacokinetics-related drug-xenobiotics interactions leading to toxic and/or adverse effects. It underlines the importance of predictions of which isoforms of CYPs are affected by triazole fungicides.

The predicted values of the skin penetration coefficients in logarithmic values ( $\left.\log K_{\mathrm{p}}\right)$ of investigated triazole fungicides were compared with those of diclofenac (a compound with a good skin penetration, $\log K \mathrm{p}=-4.96$ ), and of oubain (a compound that is not able to penetrate skin, log $K_{\mathrm{p}}=-11.07$ ) [22]. The more negative value of computed $\log K_{\mathrm{p}}$ means lower skin permeability for the investigated compound. This comparison illustrates the medium ability of triazole fungicides to penetrate skin and it is in good correlation with data proving that some of the investigated fungicides produce skin irritations (see Table 1). We have also evaluated the skin sensitization potential of investigated triazole fungicides using PredSkin computational tool and the results are illustrated in Table 4. The probability map illustrating the predicted contribution to skin sensitization potential of chemical fragments of cyproconazole when using the binary prediction based on human skin sensitization model is shown in Figure $2 \mathrm{~A}$.

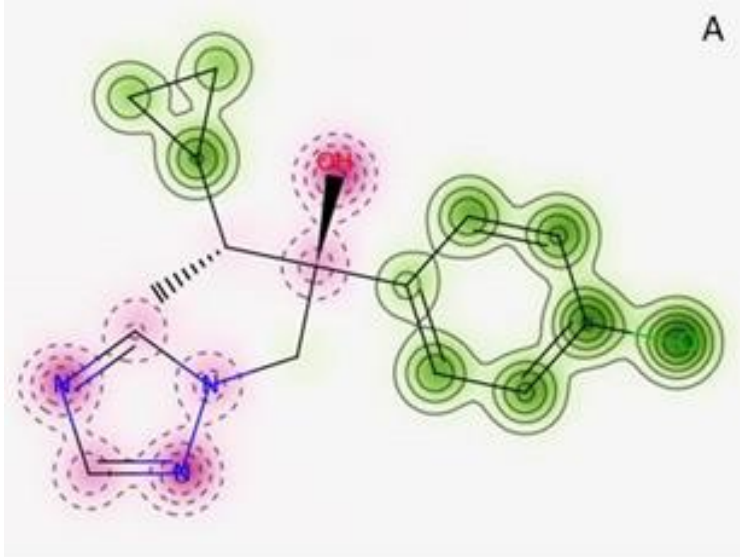

A

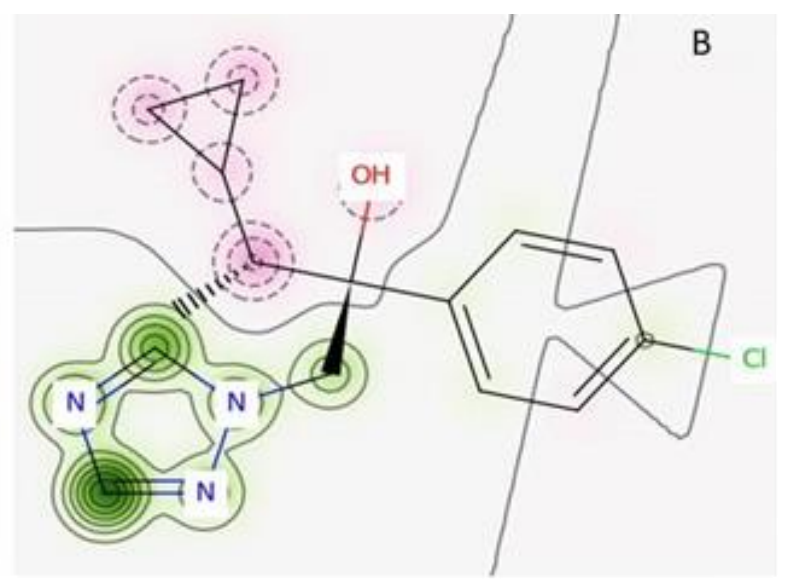

Figure 2. The redicted probability map of the predicted contribution of chemical fragments of cyproconazole to: (A) skin sensitization potential; (B) blockage of the hERG K+ channels. Green color corresponds to atoms illustrating an increase in skin sensitization (A) or towards blockage of hERG (B), pink color corresponds to atoms emphasizing a decrease in skin sensitization (A) or in hERG blockage (B) and gray lines delimit the region of split between the positive and negative contributors toward skin sensitization (A) or hERG blockage

(B). More continuous contour lines mean an increased pozitive contribution and more dashed contour lines mean an increased negative contribution of an atom to skin sensitization (A) or hERG blockage (B) respectively. 
This picture illustrates the positive contribution to skin sensitization of the chlorophenyl and cyclopropyl groups, but not of triazole ring. Table 4 illustrates that all investigated triazole fungicides are predicted as skin sensitizers. Available information concerning the ability of some of the investigated fungicides to produce skin irritations corresponds to an acute exposure. Our predictions reveal that exposure (especially when prolonged) to these compounds may conduct to skin sensitization, a complex immunological disease that have an important impact on quality of life and on working ability.

Table 4. Prediction of skin sensitization potential of the considered triazole fungicides: LLNA - murine local lymph node assay, DRPA - direct peptide reactivity assay, h-CLAT - human cell line activation test. Green boxes correspond to predictions of non-sensitizer potential, orange boxes to predictions of moderate skin sensitizer potential and red boxes illustrate predictions of skin sensitizer potential. Numbers in parenthesis correspond to the accuracy of every prediction.

\begin{tabular}{|c|c|c|c|c|c|c|}
\hline \multirow{2}{*}{ Fungicide } & \multirow{2}{*}{$\begin{array}{l}\text { Human skin } \\
\text { sensitization } \\
\text { Binary } \\
\text { prediction }\end{array}$} & \multicolumn{2}{|c|}{ LLNA } & \multirow{2}{*}{$\begin{array}{l}\text { DPRA } \\
\text { Binary } \\
\text { prediction }\end{array}$} & \multirow{2}{*}{$\begin{array}{l}\quad \text { h-CLAT) } \\
\text { Binary } \\
\text { prediction }\end{array}$} & \multirow{2}{*}{\begin{tabular}{|l} 
KeratinoSens \\
Binary \\
prediction
\end{tabular}} \\
\hline & & $\begin{array}{l}\text { Binary } \\
\text { prediction }\end{array}$ & $\begin{array}{l}\text { Multiclass } \\
\text { prediction }\end{array}$ & & & \\
\hline Cyproconazole & $\begin{array}{c}\text { Sensitizer } \\
(70 \%)\end{array}$ & $\begin{array}{c}\text { Non-Sensitizer } \\
(50 \%)\end{array}$ & $\begin{array}{c}\text { Moderate } \\
(70 \%)\end{array}$ & $\begin{array}{c}\text { Sensitizer } \\
(90 \%)\end{array}$ & $\begin{array}{l}\text { Sensitizer } \\
(80 \%)\end{array}$ & $\begin{array}{c}\text { Sensitizer } \\
(80 \%)\end{array}$ \\
\hline epoxiconazole & $\begin{array}{c}\text { Sensitizer } \\
(80 \%)\end{array}$ & $\begin{array}{c}\text { Non-Sensitizer } \\
(60 \%)\end{array}$ & $\begin{array}{c}\text { Moderate } \\
(60 \%)\end{array}$ & $\begin{array}{c}\text { Sensitizer } \\
(90 \%)\end{array}$ & $\begin{array}{c}\text { Sensitizer } \\
(80 \%)\end{array}$ & $\begin{array}{l}\text { Sensitizer } \\
(80 \%)\end{array}$ \\
\hline flutriafol & $\begin{array}{c}\text { Sensitizer } \\
(80 \%)\end{array}$ & $\begin{array}{c}\text { Non-Sensitizer } \\
(50 \%)\end{array}$ & $\begin{array}{c}\text { Moderate } \\
(80 \%)\end{array}$ & $\begin{array}{c}\text { Sensitizer } \\
(90 \%)\end{array}$ & $\begin{array}{l}\text { Sensitizer } \\
(80 \%)\end{array}$ & $\begin{array}{l}\text { Sensitizer } \\
(80 \%)\end{array}$ \\
\hline metconazole & $\begin{array}{c}\text { Sensitizer } \\
(80 \%)\end{array}$ & $\begin{array}{c}\text { Non-Sensitizer } \\
(50 \%)\end{array}$ & $\begin{array}{c}\text { Moderate } \\
(80 \%)\end{array}$ & $\begin{array}{c}\text { Sensitizer } \\
(90 \%)\end{array}$ & $\begin{array}{c}\text { Sensitizer } \\
(80 \%)\end{array}$ & $\begin{array}{l}\text { Sensitizer } \\
(80 \%)\end{array}$ \\
\hline paclobutrazol & $\begin{array}{c}\text { Sensitizer } \\
(60 \%)\end{array}$ & $\begin{array}{c}\text { Non-Sensitizer } \\
(50 \%)\end{array}$ & $\begin{array}{c}\text { Moderate } \\
(80 \%)\end{array}$ & $\begin{array}{c}\text { Sensitizer } \\
(90 \%)\end{array}$ & $\begin{array}{l}\text { Sensitizer } \\
(80 \%)\end{array}$ & $\begin{array}{l}\text { Sensitizer } \\
(80 \%)\end{array}$ \\
\hline tebuconazole & $\begin{array}{c}\text { Sensitizer } \\
(70 \%)\end{array}$ & Sensitizer (50\%) & $\begin{array}{c}\text { Moderate } \\
(90 \%)\end{array}$ & $\begin{array}{c}\text { Sensitizer } \\
(90 \%)\end{array}$ & $\begin{array}{c}\text { Sensitizer } \\
(80 \%)\end{array}$ & $\begin{array}{l}\text { Sensitizer } \\
(80 \%)\end{array}$ \\
\hline tetraconazole & $\begin{array}{c}\text { Sensitizer } \\
(60 \%)\end{array}$ & $\begin{array}{c}\text { Non-Sensitizer } \\
(50 \%)\end{array}$ & $\begin{array}{c}\text { Moderate } \\
(80 \%)\end{array}$ & $\begin{array}{c}\text { Sensitizer } \\
(90 \%)\end{array}$ & $\begin{array}{l}\text { Sensitizer } \\
(80 \%)\end{array}$ & $\begin{array}{c}\text { Sensitizer } \\
(90 \%)\end{array}$ \\
\hline triticonazole & $\begin{array}{c}\text { Sensitizer } \\
(60 \%)\end{array}$ & $\begin{array}{c}\text { Non-Sensitizer } \\
(50 \%)\end{array}$ & $\begin{array}{c}\text { Moderate } \\
(70 \%)\end{array}$ & $\begin{array}{c}\text { Sensitizer } \\
(90 \%)\end{array}$ & $\begin{array}{c}\text { Sensitizer } \\
(80 \%)\end{array}$ & $\begin{array}{c}\text { Sensitizer } \\
(90 \%)\end{array}$ \\
\hline triadimenol & $\begin{array}{c}\text { Non- } \\
\text { Sensitizer } \\
(60 \%)\end{array}$ & $\begin{array}{c}\text { Non-Sensitizer } \\
(60 \%)\end{array}$ & $\begin{array}{l}\text { Moderate } \\
(70 \%)\end{array}$ & $\begin{array}{c}\text { Sensitizer } \\
(90 \%)\end{array}$ & $\begin{array}{l}\text { Sensitizer } \\
(80 \%)\end{array}$ & $\begin{array}{l}\text { Sensitizer } \\
(80 \%)\end{array}$ \\
\hline
\end{tabular}

Table 5 contains predictions of the following toxicological endpoints of the investigated triazole fungicides: cardiotoxicity (blocking potential of h-ERG K+ channels) obtained using Pred-hERG tool, mutagenicity obtained using Toxtree software and carcinogenicity using both Toxtree and CarcinoPred-El computational facilities. The two models used by Pred-hERG tool give contradictory predictions. For all the investigated tiazole fungicides, the use of multiclass model do not predict the blockage of the hERG $\mathrm{K}+$ channels potential, but the use of the binary model reveal their potential to block the hERG K+ channels. Taking into account that the binary model has a higher accuracy of predictions, we consider that investigated triazole fungicides reflect potential to block the hERG $\mathrm{K}+$ channels. Figure $2 \mathrm{~B}$ shows the probability map of the predicted contribution of atoms and/or fragments of cyproconazole toward blockage of the hERG K+ channels. It illustrates that triazole fragment and the halogen atom reveal potential of the blockage of the hERG K+ channels. Besides the triazole ring, there is at list one fragment containing a halogen atom attached to the phenyl group in every of investigated fungicides (see Figure 1) and it reflects the hERG $\mathrm{K}+$ channel-blocking potential of these pesticides. Our findings are in good correlation with published data revealing that compounds containing a polar group (such as a halogen atom) attached to the phenyl ring at one end of the molecule reveal hERG K+ channel-blocking potential $[36,37]$. Furthermore, the class of antifungal triazoles used as human drugs [38] and other compounds 
containing the triazole ring [39] are recognized as being able to cause cardiac dysrhythmias by blocking hERG K+ channels in the heart.

Table 5. Predictions concerning the following toxicological endpoints: cardiotoxicity, carcinogenicity and mutagenicity of investigated triazole fungicides.

\begin{tabular}{|c|c|c|c|c|c|c|c|c|}
\hline \multirow[b]{2}{*}{ Fungicide } & \multicolumn{2}{|c|}{$\begin{array}{l}\text { h_ERG channel blockage } \\
\text { predictions }\end{array}$} & \multicolumn{3}{|c|}{$\begin{array}{l}\text { CarcinoPred-EL predictions } \\
\text { for carcinogenicity }\end{array}$} & \multicolumn{3}{|c|}{ Toxtree predictions } \\
\hline & $\begin{array}{l}\text { binary } \\
\text { model }\end{array}$ & $\begin{array}{l}\text { multiclass } \\
\text { model }\end{array}$ & $\begin{array}{l}\text { XGBoost } \\
\text { model }\end{array}$ & $\begin{array}{l}\text { RF } \\
\text { model }\end{array}$ & $\begin{array}{l}\text { SVM } \\
\text { model }\end{array}$ & $\begin{array}{l}\text { genotoxic } \\
\text { carcino- } \\
\text { genicity }\end{array}$ & $\begin{array}{l}\text { non } \\
\text { genotoxic } \\
\text { carcino- } \\
\text { genicity }\end{array}$ & $\begin{array}{l}\text { Ames } \\
\text { muta- } \\
\text { genicity }\end{array}$ \\
\hline cyproconazole & $\begin{array}{l}\text { blocker } \\
(70 \%)\end{array}$ & $\begin{array}{l}\text { Non-Blocker } \\
(70 \%)\end{array}$ & No & No & No & No & Yes & No \\
\hline epoxiconazole & $\begin{array}{l}\text { blocker } \\
(70 \%)\end{array}$ & $\begin{array}{l}\text { Non-Blocker } \\
(60 \%)\end{array}$ & No & No & No & yes & Yes & No \\
\hline flutriafol & $\begin{array}{l}\text { blocker } \\
(60 \%)\end{array}$ & $\begin{array}{l}\text { Non-Blocker } \\
(70 \%)\end{array}$ & Yes & Yes & Yes & No & No & No \\
\hline metconazole & $\begin{array}{l}\text { blocker } \\
(80 \%)\end{array}$ & $\begin{array}{l}\text { Non-Blocker } \\
(70 \%)\end{array}$ & No & No & No & No & Yes & No \\
\hline paclobutrazole & $\begin{array}{l}\text { blocker } \\
(70 \%)\end{array}$ & $\begin{array}{l}\text { Non-Blocker } \\
(60 \%)\end{array}$ & Yes & No & No & No & Yes & No \\
\hline tebuconazole & $\begin{array}{l}\text { blocker } \\
(70 \%)\end{array}$ & $\begin{array}{l}\text { Non-Blocker } \\
(60 \%)\end{array}$ & No & No & No & No & Yes & No \\
\hline tetraconazole & $\begin{array}{l}\text { blocker } \\
(70 \%)\end{array}$ & $\begin{array}{l}\text { Non-Blocker } \\
(70 \%)\end{array}$ & No & No & No & No & No & No \\
\hline triadimenol & $\begin{array}{l}\text { blocker } \\
(60 \%)\end{array}$ & $\begin{array}{l}\text { Non-Blocker } \\
(70 \%)\end{array}$ & Yes & No & No & No & Yes & No \\
\hline triticonazole & $\begin{array}{c}\text { blocker } \\
\text { (70\%) }\end{array}$ & $\begin{array}{l}\text { Non-Blocker } \\
(60 \%)\end{array}$ & Yes & No & No & No & Yes & No \\
\hline
\end{tabular}

The outcomes of CarcinoPred-El computational tool reveal carcinogenic potential for flutriafol, paclobutrazole, triadimenol and triticonazole when using XGBoost ensemble learning model, this model giving the highest accuracy of predictions. Only flutriafol is predicted as carcinogen by all models considered by CarcinoPred-EL tool. Toxtree outcomes are quite different by comparison with those of CracinoPred-EL and reveal both genotoxic and non-genotoxic carcinogenicity for epoxiconazole and, excepting flutriafol, non-genotoxic carcinogenicity for all the other investigated triazole fungicides. Literature data show that most of the investigated triazole fungicides are considered as probable human carcinogen. Usually, the predictions obtained with the two computational tools are not in agreement each other or with known information concerning the carcinogenic effects of triazole fungicides. It underlines the need of further investigations concerning the carcinogenic potential of triazole fungicides on humans.

Predictions obtained using ENDOCRINE DISRUPTOME computational tool reflected that investigated triazole fungicides are able to influence the activity of some of the human nuclear receptors, as presented in Table 6. Red boxes correspond to the high probability of binding, orange boxes to intermediate probability of binding, yellow boxes to moderate probability of binding and green boxes correspond to low probability of binding of triazole fungicides to these receptors. All investigated triazole fungicides are predicted as revealing antagonistic effects on the androgen receptor. Epoxiconazole is the compound predicted as reflecting the highest endocrine disruption potential as it interacts with numerous human nuclear receptors. The predictions of ENDOCRINE DISRUPTOME tool reveal that the most affected nuclear receptors by the analysed triazole fungicides are: $A R, E R \alpha, E R \beta, G R, T R \alpha$ and $T R \beta$. This result is in good agreement with published data revealing the ability of triazole fungicides to interact with nuclear receptors, especially with the androgen and estrogen receptors [12, 40-33]. 
Table 6. Prediction of the endocrine disruption potential of investigated triazole fungicides: red boxes correspond to the high probability of binding, orange boxes correspond to intermediate probability of binding, yellow boxes correspond to moderate probability of binding and green boxes correspond to low probability of binding of triazole fungicides to these receptors.

\begin{tabular}{|l|l|l|l|l|l|l|l|l|l|l|l|l|l|l|l|l|}
\hline Fungicide & AR & $\begin{array}{l}\text { AR } \\
\text { an }\end{array}$ & ER $\alpha$ & $\begin{array}{l}\text { ER } \alpha \\
\text { an }\end{array}$ & ER $\beta$ & $\begin{array}{l}\text { ER } \beta \\
\text { an }\end{array}$ & GR & $\begin{array}{l}\text { GR } \\
\text { an }\end{array}$ & LXR $\alpha$ & $\begin{array}{l}\text { LXR } \\
\beta\end{array}$ & $\begin{array}{l}\text { PPAR } \\
\alpha\end{array}$ & $\begin{array}{l}\text { PPAR } \\
\beta\end{array}$ & $\begin{array}{l}\text { PPAR } \\
\gamma\end{array}$ & $\begin{array}{l}\text { RX } \\
\text { R } \alpha\end{array}$ & TR $\alpha$ & TR $\beta$ \\
\hline $\begin{array}{l}\text { Cypro- } \\
\text { conazole }\end{array}$ & -6.5 & -7.4 & -7.8 & -7.9 & -7.6 & -7.5 & -7.3 & -6.9 & -8.4 & -8.2 & -6.7 & -7.0 & -6.7 & -7.6 & -7.5 & -7.7 \\
\hline Flutriafol & -6.3 & -8.3 & -8.7 & -8.7 & -8.7 & -8.6 & -7.9 & -7.8 & -9.1 & -8.8 & -7.9 & -7.7 & -7.4 & -8.3 & -7.9 & -8.8 \\
\hline $\begin{array}{l}\text { Tebu- } \\
\text { conazole }\end{array}$ & -7.3 & -7.5 & -7.8 & -7.1 & -7.5 & -7.2 & -7.2 & -6.6 & -8.6 & -8.3 & -7.1 & -7.2 & -7.7 & -8.5 & -6.9 & -7.8 \\
\hline $\begin{array}{l}\text { Triti- } \\
\text { conazole }\end{array}$ & -5.3 & -7.3 & -8.5 & -7.8 & -8.1 & -7.7 & -8.3 & -7.2 & -8.7 & -9.3 & -7.1 & -7.3 & -8.4 & -9.9 & -6.2 & -8.0 \\
\hline $\begin{array}{l}\text { Epoxy- } \\
\text { conazole }\end{array}$ & -8.3 & -9.2 & -9.2 & -9.3 & -8.8 & -8.9 & -8.5 & -7.9 & -10.0 & -9.4 & -8.4 & -8.0 & -8.0 & -9.0 & -8.0 & -8.6 \\
\hline $\begin{array}{l}\text { Tetra- } \\
\text { conazole }\end{array}$ & -7.2 & -7.9 & -8.3 & -8.1 & -8.2 & -7.7 & -7.5 & -7.2 & -8.9 & -8.6 & -7.5 & -7.9 & -7.8 & -8.4 & -7.9 & -8.4 \\
\hline $\begin{array}{l}\text { Tria- } \\
\text { dimenol }\end{array}$ & -6.8 & -7.7 & -7.8 & -7.6 & -7.8 & -7.4 & -7.1 & -6.8 & -8.4 & -8.1 & -7.3 & -7.1 & -7.8 & -7.9 & -7.1 & -8.3 \\
\hline $\begin{array}{l}\text { Prothio- } \\
\text { conazole }\end{array}$ & -7.3 & -7.6 & -8.3 & -8.0 & -8.2 & -7.4 & -8.2 & -7.0 & -8.5 & -8.4 & -7.7 & -7.3 & -7.4 & -8.0 & -8.3 & -7.9 \\
\hline $\begin{array}{l}\text { Met- } \\
\text { conazole }\end{array}$ & -6.5 & -7.4 & -7.8 & -8.1 & -8.6 & -8.2 & -7.8 & -7.1 & -9.1 & -9.5 & -7.9 & -7.8 & -8.1 & -9.0 & -6.7 & -8.0 \\
\hline $\begin{array}{l}\text { Paclo- } \\
\text { butrazol }\end{array}$ & -6.9 & -7.7 & -7.9 & -7.7 & -7.6 & -7.4 & -7.3 & -6.6 & -8.2 & -8.3 & -7.1 & -7.1 & -8.0 & -8.4 & -6.8 & -7.8 \\
\hline
\end{tabular}

\section{Conclusions}

Within this study we have considered 9 triazole fungicides commonly used for cereal crops protection. We have summarized the available data that support their effects on humans and we have also used various computational tools to predict their harmful effects. Available data are incomplete and the outcomes of this predictive study are meant to obtain a widely view concerning the harmful effects of these pesticides. The predictions that we have obtained using various tools usually are in good agreement with each other and with available data, this accord increasing their relevance. Triazole fungicides considered in this study are predicted as revealing high oral bioavailability, being able to penetrate the blood brain barrier, and to interact with P-glycoprotein and with hepatic CYPs.

The predicted toxicological endpoints of studied triazole fungicides are: (i) skin sensitising potential; (ii) blockage of the hERG K+ channels and (iii) endocrine disruption potential, the most affected human nuclear receptor being the androgen receptor, estrogen receptors $\alpha$ and $\beta$, glucocorticoid receptor and thyroid receptors $\alpha$ and $\beta$. Triazole fungicides considered in this study are predicted to have not mutagenic potential and their carcinogenic potential is not clear.

Of the investigated fungicides, our predictions show that epoxiconazole and triadimenol seem to have the highest potentials of producing harmful effects on humans and their use should be avoid or limited. As the use of triazole fungicides is increasing, the outcomes of our study are important for both population and professional exposure.

Conflict of interest: The authors declare no conflict of interest. 


\section{References}

[1] M.I. Pinto, H.D. Burrows, G. Sontag, C. Vale, J.P. Noronha. Priority pesticides in sediments of European coastal lagoons: A review. Marine Pollution Bulletin 112 (2016) 6-16. (https://www.sciencedirect.com/science/article/pii/S0025326X16305069?via\%3Dihub)

[2] N.I. Rousis, E. Zuccato, S. Castiglioni. Monitoring population exposure to pesticides based on liquid chromatography-tandem mass spectrometry measurement of their urinary metabolites in urban wastewater: a novel biomonitoring approach. Science of the Total Environment 571 (2016) 13491357. (https://www.sciencedirect.com/science/article/pii/S0048969716314814)

[3] V. Yusa, M. Millet, C. Coscolla, O. Pardo, M. Roca. Occurrence of biomarkers of pesticide exposure in non-invasive human specimens. Chemosphere 139 (2015) 91-108. (https://www.sciencedirect.com/science/article/pii/S0045653515005639?via\%3Dihub)

[4] C.A. Damalas, I.G. Eleftherohorinos. Pesticide exposure, safety issues, and risk assessment indicators. International Journal of Environmental Research and Public Health 8 (2011) 1402-1419. (https://www.ncbi.nlm.nih.gov/pmc/articles/PMC3108117/)

[5] V. Yusa, M. Millet, C. Coscolla, M. Roca, Analytical methods for human biomonitoring of pesticides. A review. Analytica Chimica Acta 891 (2015) 15-31. (https://www.sciencedirect.com/science/article/pii/S0003267015007552?via\%3Dihub)

[6] K.H. Kim, E. Kabir, S.A. Jahan. Exposure to pesticides and the associated human health effects. Science of the Total Environment 575 (2017) 525-535. (https://www.sciencedirect.com/science/article/pii/S004896971631926X?via\%3Dihub)

[7] S.C. Machado, I. Martins. Risk assessment of occupational pesticide exposure: Use of endpoints and surrogates. Regulatory Toxicology and Pharmacology 98 (2018) 276-283. (https://www.sciencedirect.com/science/article/pii/S0273230018302198?via\%3Dihub)

[8] W.J. Zhang. Global pesticide use: Profile, trend, cost / benefit and more. Proceedings of the International Academy of Ecology and Environmental Sciences 8 (2018) 1-27. (http://www.iaees.org/publications/journals/piaees/articles/2011-1(2)/Global-pesticide-consumptionpollution.pdf)

[9] E. Giavini, E. Menegola. Are azole fungicides a teratogenic risk for human conceptus? Toxicology Letters 198 (2010) 106-111. (https://www.sciencedirect.com/science/article/pii/s0378427410015870?via\%3Dihub)

[10] A. Chowdhary, S. Kathuria, H.S. Randhawa, S.N. Gaur, C.H. Klaassen. Isolation of multiple-triazoleresistant Aspergillus fumigatus strains carrying the TR/L98H mutations in thecyp51A gene in India. Journal of Antimicrobial Chemotherapy 67 (2012) 362-366. (https://academic.oup.com/jac/article/67/2/362/700010)

[11] F.J. Machado, F.M. Santana, D. Lau, E.M.D. Ponte. Quantitative review of the effects of triazole and benzimidazole fungicides on Fusarium head blight and wheat yield in Brazil. Plant Disease 101 (2017) 1633-1641. (https://apsjournals.apsnet.org/doi/10.1094/PDIS-03-17-0340-RE)

[12] X. Lv, L. Pan, J. Wang, L. Lu, W. Yan, Y. Zhu, Y. Xu, M. Guo, S. Zhuang. Effects of triazole fungicides on androgenic disruption and CYP3A4 enzyme activity. Environmental pollution 22 (2017) 504-512. (https://www.sciencedirect.com/science/article/pii/S0269749116308612?via\%3Dihub)

[13] EU Pesticides database - European Commission, http://ec.europa.eu/food/plant/pesticides/eupesticides-database/public/?event=homepage\&language=EN (accessed between December 2018 and February 2019).

[14] National Research Council. 2004. Intentional Human Dosing Studies for EPA Regulatory Purposes: Scientific and Ethical Issues. Washington, DC: The National Academies Press. https://www.nap.edu/read/10927/chapter/1 (accessed on 25 January 2019).

[15] Guidance document on the validation of (Quantitative)Structure-Activity Relationships [(Q)SAR] Models. OECD 69 (2007) (https://read.oecd-ilibrary.org/environment/guidance-document-on-thevalidation-of-quantitative-structure-activity-relationship-q-sar-models 9789264085442-en\#page1 - accessed on 18 Avril 2019). 
[16] European Food Safety Authority, Modern methodologies and tools for human hazard assessment of chemicals, EFSA Journal 12 (2014) 3638. (https://efsa.onlinelibrary.wiley.com/doi/pdf/10.2903/i.efsa.2014.3638 - accessed on 18 Avril 2019).

[17] D. Craciun, D. Modra, A. Isvoran. ADME-Tox profiles of some food additives and pesticides, AIP Conference Proceedings 1694 (2015) 040007. (https://doi.org/10.1063/1.4937259)

[18] A. Isvoran, A. Ciorsac, V. Ostafe. ADME-Tox profiling of some low molecular weight water soluble chitosan derivatives, ADMET and DMPK 5 (2017) 192-200. (http://dx.doi.org/10.5599/admet.$\underline{5.3 .423})$

[19] M. Roman, D.L. Roman, V. Ostafe, A. Ciorsac. Computational assessment of pharmacokinetics and biological effects of some anabolic and androgenic steroids. Pharmaceutical Research 35 (2018) 41. (doi: http://dx.doi.org/10.1007/s11095-018-2353-1)

[20] M. Roman, D.L. Roman, V. Ostafe, A. Isvoran. Computational Assessment of Biological Effects of Methyl-,Ethyl-, Propyl- and Butyl-Parabens. Journal of Bioinformatics, Genomics, Proteomics 3 (2018) 1029.

[21] V.M. Alves, E.N. Muratov, A. Zakharov, N.N. Muratov, C.H. Andrade, A. Tropsha. Chemical toxicity prediction for major classes of industrial chemicals:Is it possible to develop universal models covering cosmetics, drugs, and pesticides?. Food and Chemical Toxicology 112 (2018) 526-534. (https://www.ncbi.nlm.nih.gov/pmc/articles/PMC5638676/)

[22] D. Lagorce, L. Bouslama, J. Becot, M.A. Miteva, B.O. Villoutreix. FAF-Drugs4: free ADME-tox filtering computations for chemical biology and early stages drug discovery. Bioinformatics 33 (2017) 36583660. (https://academic.oup.com/bioinformatics/article/33/22/3658/4056067)

[23] R.F. Bruns, I.A. Watson. Rules for Identifying Potentially Reactive or Promiscuous Compounds. Journal of Medicinal Chemistry 55 (2012) 9763-9772. (https://pubs.acs.org/doi/10.1021/im301008n)

[24] A. Daina, O. Michielin, V. Zoete. SwissADME: a free web tool to evaluate pharmacokinetics, druglikeness and medicinal chemistry friendliness of small molecules. Scientific Reports 7 (2017) 42717. (https://www.ncbi.nlm.nih.gov/pmc/articles/PMC5335600/)

[25] R.C. Braga, V.M. Alves, E.N. Muratov, J. Strickland, N. Kleinstreuer, A. Trospsha, C.H. Andrade. PredSkin: A Fast and Reliable Web Application to Assess Skin Sensitization Effect of Chemicals. Journal of Chemical Information and Modeling 57 (2017) 1013-1017. (https://pubs.acs.org/doi/10.1021/acs.jcim.7b00194)

[26] R.C. Braga, V.M. Alves, M.F. Silva, E. Muratov, D. Fourches, L.M. Lião, A. Tropsha, C.H. Andrade. Pred-hERG: A Novel web-Accessible Computational Tool for Predicting Cardiac Toxicity. Molecular Informatics 34 (2015) 698-701. (https://www.ncbi.nlm.nih.gov/pmc/articles/PMC5720373/)

[27] L. Zhang, H. Ai, W. Chen, Z. Yin, H. Hu, J. Zhu, J. Zhao, Q. Zhao, H. Liu. CarcinoPred-EL: Novel models for predicting the carcinogenicity of chemicals using molecular fingerprints and ensemble learning methods. Scientific Reports 7 (2017) 2118. (https://www.ncbi.nlm.nih.gov/pmc/articles/PMC5437031/)

[28] G. Patlewicz, N. Jeliazkova , R.J. Safford, A.P. Worth, B. Aleksiev. An evaluation of the implementation of the Cramer classification scheme in the Toxtree software, SAR and QSAR in Environmental Research 19 (2008) 495-524. (https://www.tandfonline.com/doi/abs/10.1080/10629360802083871)

[29] R. Benigni, C. Bossa, T. Netzeva, A. Rodomonte, I. Tsakovska. Mechanistic QSAR of aromatic amines: new models for discriminating between mutagens and nonmutagens, and validation of models for carcinogen. Environmental and Molecular Mutagenesis 48 (2007) 754-771. (https://onlinelibrary.wiley.com/doi/abs/10.1002/em.20355)

[30] K. Kolsek, J. Mavri, M. SollnerDolenc, S. Gobec, S. Turk. Endocrine disruptome - an open source prediction tool for assessing endocrine disruption potential through nuclear receptor binding. Journal of Chemical Information and Modeling 54 (2014) 1254-1267. (https://pubs.acs.org/doi/10.1021/ci400649p) 
[31] X. Shen, F. Chen, L. Chen, Y. Su, P. Huang, R.-S. Ge. Effects of Fungicides on Rat's Neurosteroid Synthetic Enzymes, BioMed Research International 2017 (2017) 5829756.

[32] N.M. Filipov, D.A. Lawrence. Developmental Toxicity of a Triazole Fungicide: Consideration of Interorgan Communication. Toxicological Sciences 62 (2001) 185-186. (https://academic.oup.com/toxsci/article/62/2/185/1663615)

[33] M. Chaâbane, I. Ghorbel, A. Elwej, H. Mnif, T. Boudawara, S. Ellouze Chaâbouni, N. Zeghal, N. Soudani. Penconazole alters redox status, cholinergic function, and membrane-bound ATPases in the cerebrum and cerebellum of adult rats. Human \& Experimental Toxicology 36 (2016) 854-866. (https://journals.sagepub.com/doi/abs/10.1177/0960327116672911)

[34] V.J. Lempers, J.J. van den Heuvel, F.G. Russel, R.E. Aarnoutse, D.M. Burger, R.J. Brüggemann, J.B. Koenderink. Inhibitory potential of antifungal drugs on atp-binding cassette transporters $\mathrm{p}$ glycoprotein, MRP1 to MRP5, BCRP, and BSEP. Antimicrobial Agents and Chemotherapy 60 (2016) 3372-3379. (https://www.ncbi.nlm.nih.gov/pmc/articles/PMC4879353/)

[35] J.R. Amsden, P.O. Gubbins. Pharmacogenomics of triazole antifungal agents: implications for safety, tolerability and efficacy. Expert Opinion on Drug Metabolism\&Toxicology 13 (2017) 1135-1146. (https://www.tandfonline.com/doi/abs/10.1080/17425255.2017.1391213?src=recsys\&journalCod e=iemt20)

[36] P.O. Gubbins. Triazole antifungal agents drug--drug interactions involving hepatic cytochrome P450. Expert Opinion on Drug Metabolism\&Toxicology 7 (2011) 1411-1429. (https://www.tandfonline.com/doi/abs/10.1517/17425255.2011.627854?journalCode=iemt20)

[37] A. Cavalli, E. Poluzzi, F. De Ponti, M. Recanatini. Toward a pharmacophore for drugs inducing the long QT syndrome: insights from a CoMFA study of HERG K_ channel blockers. Journal of Medicinal Chemistry 45 (2002) 3844-385. (https://pubs.acs.org/doi/abs/10.1021/im0208875)

[38] M. Perry, M.J. de Groot, R. Helliwell, D. Leishman, M. Tristani-Firouzi, M.C. Sanguinetti, J. Mitcheson. Structural determinants of HERG channel block by clofilium and ibutilide. Molecular Pharmacology 66 (2004) 240-249. (http://molpharm.aspetjournals.org/content/66/2/240.long)

[39] K. Arunrungvichian, P. Khongkaew, S. Panyasang, J. Sarasamkan. Preliminary in vitro permeability, cytotoxicity and cardiotoxicity evaluation of triazole-quinuclidine T6. Pharmaceutical Sciences Asia 46 (2019) 156-162. (https://www.pharmacy.mahidol.ac.th/journal/_files/2019-46-3_156-162.pdf)

[40] D. Schrey, T.J. Walsh, A.H. Groll. Antifungal drugs. Side Effects of Drugs Annual 33 (2011) 541-566. (https://www.sciencedirect.com/science/article/pii/B9780444537416000271?via\%3Dihub)

[41] M.B. Kjaerstad, C. Taxvig, C. Nellemann, A.M. Vinggaard, H.R. Andersen. Endocrine disrupting effects in vitro of conazole antifungals used as pesticides and pharmaceuticals. Reproductive Toxicology 30 (2010) 573-582. (https://www.sciencedirect.com/science/article/pii/S0890623810002625?via\%3Dihub)

[42] T. Mankame, R. Hokanson, R. Chowdhary, D. Busbee. Altered gene expression in human cells induced by the agricultural chemicals Enable. Toxicology and Industrial Health 20 (2004) 89-102. (https://journals.sagepub.com/doi/abs/10.1191/0748233704th1980a)

[43] S. Rieke, S. Koehn, K. Hirsch-Ernst, R. Pfeil, C. Kneuer, P. Marx-Stoelting. Combination effects of (tri)azole fungicides on hormone production and xenobiotic metabolism in a human placental cell line. International Journal of Environmental Research and Public Health 11 (2014) 9660-9679. (https://www.ncbi.nlm.nih.gov/pmc/articles/PMC4199042/pdf/ijerph-11-09660.pdf) 